\title{
Studies on physico-chemical parameters of biscuits using wheat, sorghum and groundnut blend flour
}

\author{
Rohit Kumar Maurya and Devendra Kumar
}

\begin{abstract}
Biscuits are feasible to provide complete enrichment and contain different amount of protein, fat, mineral, carbohydrate and calorific energy. Experiments were conducted to evaluate quality attributes of biscuits using wheat, sorghum and groundnut blend flour. Study was also conducted to see the effect of blend flours treatments on physico-chemical parameters. Flours blend were prepared with various combination of wheat, sorghum and groundnut as $\mathrm{W}_{80}: \mathrm{S}_{15}: \mathrm{G}_{05}\left(\mathrm{~T}_{1}\right)$, $\mathrm{W}_{70}: \mathrm{S}_{20}: \mathrm{G}_{10}\left(\mathrm{~T}_{2}\right)$ and $\mathrm{W}_{60}: \mathrm{S}_{25}: \mathrm{G}_{15}\left(\mathrm{~T}_{3}\right)$. After preparation of biscuit physico-chemical properties viz., moisture content, fat content, ash content, protein content and carbohydrate content were evaluated just fresh and after 30,60 and 90 days of storage period. The study revealed that the moisture content increased with the increase of storage period for all treatments. The value of moisture content 4.76 per cent was obtained maximum in the treatment $\mathrm{T}_{3}$ after 90 days of storage period. The ash content change with increase of storage period was slightly decreased in all treatments. The minimum ash content $(0.88 \%)$ was found in the treatment $\mathrm{T}_{3}$ after 90 days storage period. The fat content of biscuits sample decreased with increase in storage period in case of all treatments. Data obtained for protein content after 30, 60,90 days of storage indicated that in case of all samples, the value decreased for all treatments. Highest protein content $(13.5 \%)$ was observed in treatment $\mathrm{T}_{3}$ for the fresh biscuits sample. Carbohydrate content was obtained minimum in $\mathrm{T}_{3}(64.27 \%)$ at 0 day (fresh) and maximum in $\mathrm{T}_{1}(66.48 \%)$ at 90 days. The average value was calculated for diameter and thickness as $\mathrm{T}_{1}(40 \mathrm{~mm})$ and $(0.9 \mathrm{~mm}), \mathrm{T}_{2}(40 \mathrm{~mm})$ and $(0.9 \mathrm{~mm}), \mathrm{T}_{3}(40 \mathrm{~mm})$ and $(0.8 \mathrm{~mm})$, respectively. There were no changes in diameter and thickness in different treatment of biscuits because ingredients were same in all treatments. The result showed that spread ratio was observed as 44.44, 44.44 and 50 for treatments $\mathrm{T}_{1}, \mathrm{~T}_{2}$ and $\mathrm{T}_{3}$, respectively. Fresh biscuit samples with wheat flour $70 \%+$ sorghum flour $20 \%$ + groundnut flour $10 \%\left(\mathrm{~T}_{2}\right)$ rated highest score $(7.8)$ than other treatments.
\end{abstract}

Key Words : Biscuit, Blend flour, Physico-chemical, Spread ratio

How to cite this article : Maurya, Rohit Kumar and Kumar, Devendra (2020). Studies on physico-chemical parameters of biscuits using wheat, sorghum and groundnut blend flour. Food Sci. Res. J., 11(2): 77-83, DOI : 10.15740/HAS/FSRJ/11.2/77-83.Copyright@, 2020: Hind Agri-Horticultural Society.

Rohit Kumar Maurya, Dr. Bhim Rao Ambedkar College of Agricultural Engineering and Technology, Etawah (U.P.) India Email: rohitmaurya3131@gmail.com

Associate Authors'

Devendra Kumar, Dr. Bhim Rao Ambedkar College of Agricultural Engineering and Technology, Etawah (U.P.) India

Email: devendrachaturvedi2008@gmail.com 